\title{
Functionality of children aged 5 to 7 years born prematurely
}

\author{
Funcionalidade de crianças entre 5 e 7 anos nascidas prematuras
}

\author{
Natalia Trindade de Souza, Paula Silva de Carvalho Chagas, Gabriela Gomes de Campos, \\ Elisa de Jesus Valenzuela, Jaqueline da Silva Frônio, Luiz Claudio Ribeiro*
}

Universidade Federal de Juiz de Fora, Juiz de Fora (UFJF), Juiz de Fora, MG, Brazil

\begin{abstract}
Introduction: Preterm birth is one of several risk factors that can compromise child growth and development. Objective: Evaluate the functionality of 5 to 7-year-old schoolchildren born prematurely and compare them to children born full-term. Methods: This was a cross-sectional study with 110 children divided into 2 groups (55 in the preterm group - PTG; 55 in the full-term group - FTG). Sociodemographic data were collected of the families and children and the families were economically classified according to the Brazilian Economic Classification Criteria - CCEB (Brazilian Association of Market Research Companies - ABEP) Functionality was assessed using the Pediatric Evaluation of Disability Inventory (PEDI). Results: With respect to the descriptive variables, significant differences were observed for gestational age $(p<0.001)$, birth weight $(p<0.001)$, complications during the perinatal period $(\mathrm{p}<0.001)$, current diseases $(\mathrm{p}=0.010)$ and schooling level of the child $(p=0.023)$. In regard to functionality, on the Caregiver Assistance scale, a significant difference was recorded for mobility ( $p=0.009)$. Conclusion: The results of this study demonstrate that 5 to 7 -year-old schoolchildren born prematurely showed no differences in functional skills when compared to full-term children. However, the caregivers of preterm children provide greater mobility assistance compared to those caring for full-term children.
\end{abstract}

Keywords: Premature. Child Health. Children. Child Development. Functional Performance.

\footnotetext{
NTS: MS, e-mail: nataliatrindadetr@gmail.com PSCC: PhD, e-mail: paula.chagas@ufjf.edu.br GGC: BS, e-mail: biagdec@hotmail.com

EJV: BS, e-mail: elisajvalenzuela@yahoo.com.br

JSF: PhD, e-mail:jfronio@hotmail.com

LCR: PhD, e-mail: luizclaudio@ice.ufjf.br
} 
Resumo

Introdução: A prematuridade é um dos diversos fatores de risco que podem comprometer o crescimento e o desenvolvimento de crianças. Objetivo: Avaliar a funcionalidade de crianças que nasceram prematuras e se encontram na faixa etária entre 5 e 7 anos, inseridas no ambiente escolar, comparando-as com crianças nascidas a termo. Métodos: Este foi um estudo transversal com a participação de 110 crianças, divididas em 2 grupos (55 no grupo prematuro-GPT; 55 no grupo a termo-GAT). Foram coletados os dados sócio-demográficos da família e da criança e a família foi classificada economicamente pelo Critério de Classificação Econômica Brasil (ABEP). A funcionalidade foi avaliada com o Inventário de Avaliação Pediátrica de Incapacidade (PEDI). Resultados: Em relação às variáveis descritivas foram encontradas diferenças significativas na idade gestacional $(p<0,001)$, peso ao nascimento $(p<0,001)$, intercorrências no período perinatal $(p<0,001)$, doenças atuais $(p=0,010)$ e escolaridade da criança $(p=0,023)$. Com relação à funcionalidade, na parte de Assistência do Cuidador, foi encontrada diferença significativa na área de Mobilidade $(p=0,009)$. Conclusão: Os resultados deste estudo apontam que as crianças nascidas prematuras e que se encontram na faixa etária de 5 a 7 anos e inseridas no ambiente escolar quando comparadas a crianças nascidas a termo, não apresentam diferenças nas Habilidades Funcionais. Contudo, os cuidadores das crianças nascidas prematuras ofertam maior cuidado na área de mobilidade quando comparados aos cuidadores de crianças nascidas a termo.

Palavras-chave: Prematuro. Saúde da Criança. Criança. Desenvolvimento Infantil. Performance Funcional.

\section{Introduction}

The survival of infants born under adverse conditions has increased due to scientific and technological advances in obstetric care and neonatology (1 - 5). This trend is evident among preterm infants and is more pronounced in those with a low gestational age (GA) $(1,6)$. However, the decline in mortality is not accompanied by reduced morbidity $(1,2,7,8)$.

The World Health Organization (WHO) defines preterm birth as babies born alive before 37 weeks of pregnancy are completed; these infants are categorized according to GA as moderate to late preterm (32 to 37 weeks), very preterm (28 to 32 weeks) and extremely preterm (less than 28 weeks) $(9,10)$. In 2010, an estimated 15 million premature births occurred worldwide, corresponding to $11.1 \%$ of all births $(11,12)$. Brazil was ranked $10^{\text {th }}$ out of 184 countries studied in 2010 , with $9.2 \%$ of infants born prematurely $(11,12)$. Data from recent years reveal a rising trend (13 - 16), with $11.48 \%$ preterm births in 2013, according to the National Live Birth Information System (DATASUS) (17).

Premature birth is a risk factor for neonatal, early childhood and long-term morbidities. It can also contribute to neuro-psychomotor development disorders, socioeconomic and behavioral difficulties (18-22), and cause functional problems that compromise activities of daily living (ADL), extending through the child's life $(3,22)$.

According to Maggi et al. (23), it is important to monitor the development of children up to school age, focusing on motor coordination, cognitive development and functional performance. Functional assessment measures children's ability to perform ADL and carry out their socially expected role, when compared to physically and emotionally healthy children of the same age and culture ${ }^{1}$. The evaluation of children at risk for developmental issues focuses primarily on functional assessment (24). Functional assessment at preschool age allows preventive measures to be taken early and warns parents of any difficulties when children enter the school environment (23).

Although a number of studies have investigated factors that can compromise the development of preterm infants, there is still little evidence regarding the long-term impact of these factors on their functional capacity, ADL, independence and participation in their environment, especially in Brazil (25). As such, this study aimed to compare the functionality of 5 to 7-year-old schoolchildren born prematurely with those born full-term. 


\section{Methods}

Participants

This is a descriptive observational cross-sectional study. Data were collected from November 2014 to February 2015, using convenience sampling. Participants were children born prematurely and full-term in the municipality of Juiz de Fora and still residing there. This study is part of a broader project entitled "QUALITY OF LIFE AND FUNCTIONALITY OF SCHOOL AGE CHILDREN BORN PREMATURELY", approved by the Research Ethics Committee of Federal University of Juiz de Fora on November 12, 2014, under protocol number 875.927.

The preterm group (PTG) consisted of 5 to 7-year-old children born at less than 37 weeks, recruited by convenience sampling from a database compiled in a previous study (26). The second group consisted of children born full-term (FTG), between 37 and 42 weeks, with a birth weight greater than 2500 grams, matched with the PTG for age, sex and socioeconomic status (SES). To that end, the parents or legal guardians of each child in the PTG were asked to recommend neighbors, relatives, friends or pupils at the same school with the same age and gender as their child. The age range of fullterm children in relation to those born prematurely was considered in accordance with age in years (maximum 11-month interval).

Both groups contained only schoolchildren. Exclusion criteria for both groups were hospitalization in the previous six months, congenital malformation, chromosomal abnormalities and cerebral palsy. In the FTG, children with a history of perinatal complications were also excluded from the study. These exclusion criteria were established because of their potential to compromise the outcome assessed. The inability to complete the interview was considered a discontinuity criterion, with the participant subsequently excluded for not providing comprehensive information.

Instruments

Pediatric Evaluation of Disability Inventory- PEDI

The PEDI was applied to assess the functional performance of the children. The instrument was translated, adapted and validated for Brazilian
Portuguese and can be used with children aged 6 months to 7.5 years or those with motor performance within this range (27). The test assesses the daily functional skills available in the child's repertoire (Part I), their level of independence and the amount of caregiver assistance required (Part II), and the environmental modifications needed (Part III). Each of these scales evaluates three domains, namely selfcare, mobility and social function. The present study used only Parts I and II, in the form of a structured interview with the caregiver.

The first part provides information on the functional skills of the children and the second pertains to data on their level of independence when performing tasks, which is inversely proportional to the amount of assistance needed from the caregiver $(27,28)$. The data were analyzed considering the raw scores (summed scores from each scale); the scoring criteria used are described in the instrument instruction manual (27).

Brazilian Economic Classification Criteria (Brazilian Association of Market Research Companies - ABEP)

The socioeconomic status (SES) of the participants was characterized according to the ABEP. This questionnaire assesses the schooling level of the head of the family and estimates his or her purchasing power, dividing families into socioeconomic classes (A, B1, B2, C1, C2, D and E) based on the summed scores of the items evaluated, ranging from 0 to 100 (29). Since none of the participants were classified as socioeconomic class $E$, for the purpose of data analysis, the upper classes A and B were combined into Class AB (high socioeconomic status) and classes $\mathrm{C}$ and $\mathrm{D}$ into Class CD (low socioeconomic status).

In addition to the standardized instruments, a data registration protocol was devised in order to collect data related to the primary outcomes or that could interfere in this measure. In this protocol, caregivers were questioned about biological (sex, age, birth weight), family and social factors (mother's age, parent's marital status, household income and per capita household income).

\section{Procedures}

The study objectives and procedures were explained at the interview, after which written 
informed consent was given. The interview began with the researcher filling out the data registration protocol, followed by the ABEP and PEDI. For standardization purposes, the researchers were trained in the interview procedure and received written instructions, with all the interviews following the same order of application. The interviews were scheduled with parents by phone in order to select the best time and place for them as the primary caregivers. This was typically at the child's home.

The data collection team consisted of a physiotherapist and four undergraduate physiotherapy students, with each collection performed by a single member. The database entry was composed of two undergraduate physiotherapy students who were not part of the data collection team. Each participant was assessed once by a trained evaluator experienced in the application of all the instruments used, with excellent intra-rater reliability (test-retest) scores (ICC > 0.90) for the PEDI.

\section{Statistical Analysis}

Descriptive statistics were used for sample characterization, which was deemed normal. The t-test was used to assess equivalence between groups and the chi-squared and/or Fisher's exact tests to determine the association between the two categorical variables. The t-test was applied to compare functional performance between the PTG and FTG according to the raw score (continuous variable), where the PEDI scores were considered the dependent variable. A significance level of $\alpha=0.05$ was set for all statistical analyses, performed using the Statistical Package for Social Sciences (SPSS ${ }^{\circledR}$, v. 14.0).

\section{Results}

The sample consisted of 110 children aged between 5 and 7 years, 55 in the preterm group (PTG) and 55 in the full-term group (FTG).

Sample characterization in relation to the continuous variables is shown in Table 1. Given the composition of the sample, gestational age (GA) and birth weight (BW) were significantly lower in the PTG $(p<0.001)$. Table 2 shows the categorical variables, with caregivers of the PTG describing their children as having a disease more often than FTG caregivers $(p=0.010)$. With respect to complications during the perinatal period (CPP), due to a sample selection criterion these were only reported in the PTG $(\mathrm{p}<0.001)$. Moreover, significantly more children from the PTG were at an earlier stage of schooling when compared to the FTG $(p=0.023)$.

Table 1 - Characteristics of the study participants according to continuous variables

\begin{tabular}{lccc}
\hline Continuous variables & PTG (n: 55) & FTG (n: 55) & p value \\
\hline Gestational Age (weeks) & $32.16(2.80)$ & $39.02(0.95)$ & $<0.001^{\star}$ \\
Birth Weight (grams) & $1815.93(714.66)$ & $3225.07(417.69)$ & $<0.001^{\star}$ \\
Child's age (years) & $5.42(0.71)$ & $5.62(0.68)$ & 0.135 \\
Mother's age at birth (years) & $31.60(7.04)$ & $29.18(6.96)$ & 0.075 \\
Family Income (Brazilian reals) & $4812.25(4155.02)$ & $4084.95(4065.98)$ & 0.356 \\
Per capita household income (Brazilian reals) & $1042.50(1040.71)$ & $1424.41(1361.34)$ & 0.101 \\
\hline
\end{tabular}

Note: PTG: Premature group; FTG: Full-term group; n: Number of participants: Values expressed as mean and standard deviation in brackets. ${ }^{*} p<0.05$. T-test.

Table 2 - Characteristics of the study participants according to categorical variables

\begin{tabular}{lcccc}
\hline & \multicolumn{1}{c}{ Categorical variables } & PTG (n: 55) & FTG (n: 55) & p value \\
\hline Sex & Female & $27(49.1 \%)$ & $26(47.3 \%)$ & 0.849 \\
& Male & $28(50.9 \%)$ & $29(52.7 \%)$ & $<0.001^{*}$ \\
\hline CPP & Yes & $48(12.7 \%)$ & $0(0 \%)$ & $55(100 \%)$ \\
& No & $7(87.3 \%)$ & & (To be continued)
\end{tabular}


Table 2 - Characteristics of the study participants according to categorical variables

\begin{tabular}{|c|c|c|c|c|}
\hline \multicolumn{2}{|c|}{ Categorical variables } & \multirow{2}{*}{$\frac{\text { PTG (n: 55) }}{21(38.2 \%)}$} & \multirow{2}{*}{$\frac{\text { FTG (n: 55) }}{9(16.4 \%)}$} & \multirow{3}{*}{$\frac{\text { p value }}{0.010^{*}}$} \\
\hline \multirow[t]{2}{*}{ Diseases (current) } & Yes & & & \\
\hline & No & $34(61.8 \%)$ & $46(83.6 \%)$ & \\
\hline \multirow[t]{4}{*}{ Child's schooling level } & Preschool year 1 & 17 (30.9\%) & $11(20.0 \%)$ & \multirow{4}{*}{$0.023^{*}$} \\
\hline & Preschool year 2 & $28(36.4 \%)$ & $20(36.4 \%)$ & \\
\hline & Grade 1 & $6(10.9 \%)$ & $19(34.5 \%)$ & \\
\hline & Grade 2 & $4(7.3 \%)$ & $5(9.1 \%)$ & \\
\hline \multirow[t]{2}{*}{ Socioeconomic status - ABEP } & $A B$ & $29(52.7 \%)$ & $37(67.3 \%)$ & \multirow{2}{*}{0.119} \\
\hline & $C D$ & $26(47.3 \%)$ & $18(32.7 \%)$ & \\
\hline \multirow[t]{3}{*}{ Mother's schooling level } & Basic education & $19(34.5 \%)$ & $9(16.4 \%)$ & \multirow{3}{*}{0.076} \\
\hline & High school & $22(40.0 \%)$ & $25(45.5 \%)$ & \\
\hline & College & $14(25.5 \%)$ & $21(38.2 \%)$ & \\
\hline \multirow[t]{2}{*}{ Parents live together } & Yes & $44(80.0 \%)$ & $38(69.1 \%)$ & \multirow{2}{*}{0.189} \\
\hline & No & $11(20.0 \%)$ & $17(30.9 \%)$ & \\
\hline \multirow[t]{2}{*}{ Mother's job } & Employed & $39(70.9 \%)$ & $44(80.0 \%)$ & \multirow{2}{*}{0.268} \\
\hline & Unemployed & $16(29.1 \%)$ & $11(20.0 \%)$ & \\
\hline
\end{tabular}

Note: PTG: Premature group; FTG: Full-term group; CPP: Complications during the perinatal period; $n$ : Number of participants: Values expressed as absolute frequency and percentages (\%) in brackets. ${ }^{*} p<0.05$ Chi-squared or Fisher's exact test.

The raw score for each group in the PEDI is shown in Table 3. The PTG exhibited a significantly lower raw score than the FTG for the Mobility domain of the Caregiver Assistance scale (MCA) $(p=0.009)$.

Table 3 - Comparative data of the Pediatric Evaluation of Disability Inventory (PEDI) according to group

\begin{tabular}{lllc}
\hline PEDI & PTG (n: 55) & FTG (n: 55) & p value \\
\hline FSSC & $68,69(3,39)$ & $69,05(3,56)$ & 0,585 \\
FSM & $56,76(2,15)$ & $57,36(2,30)$ & 0,160 \\
FSSF & $57,05(3,55)$ & $57,31(3,23)$ & 0,695 \\
CASC & $33,49(4,91)$ & $35,22(4,25)$ & 0,051 \\
CAM & $33,18(1,74)$ & $34,04(1,62)$ & $0,009^{*}$ \\
CASF & $21,64(2,12)$ & $22,31(1,77)$ & 0,074 \\
\hline
\end{tabular}

Note: PTG: Premature group; FTG: Full-term group; PEDI = Pediatric Evaluation of Disability Inventory; FFSC = functional skills of selfcare, $F S M=$ functional skills of mobility, FSSF = Functional skills social function, CASC = caregiver assistance self-care, CAM = caregiver assistance mobility, CASF = caregiver assistance social function; $n$ : Number of participants: Values expressed as mean and standard deviation in brackets. ${ }^{*} p<0.05$. T-test.

\section{Discussion}

The results of the present study demonstrate that 5 to 7-year-old schoolchildren born prematurely exhibit no functional differences in the self-care, mobility and social function domains in relation to full-term children. With respect to caregiver assistance, the caregivers of the preterm group (PTG) provided more help in the mobilityrelated tasks.

In relation to functionality, no inter-group differences were observed on the functional skills scale; however, the literature indicates that preterm children show delayed motor development when compared to those born full-term $(1,3,8)$. Studies describe worse perceptual, motor and postural performance among premature children, even those over 4 years old (30 - 35). Nevertheless, most studies assess groups of prematurely born children without excluding those diagnosed with neuromotor impairment, which could influence the motor and functional outcomes. Children with neuromotor impairments were excluded from the present study 
in order to directly determine whether premature children would exhibit impaired functional development in the 5 to 7 -year-old age range, which could not be confirmed.

A number of studies focus on extreme prematurity (GA less than 28 weeks), while only a small portion address the development of moderate (28 to 32 weeks) to late preterm children (32 to 37 weeks), indicating a need for a broader approach by including preterm children with different gestational ages (35). The present study included children with different degrees of prematurity, meaning the mean GA and birth weight were higher than those observed in other studies. These differences may explain the disagreement between our results and those found in the literature $(30-33,36)$.

Camargos et al. (37) studied motor performance in moderate preterm schoolchildren aged 7 to 8 years and compared them to full-term children. The authors found that the former only exhibited delays in fine motor skills, with no differences in gross motor skills, balance, body schema, spatial or temporal organization. Similarly, Ribeiro et al. (38) compared the gross motor skills of premature and full-term children. The authors assessed 37 children aged between 5 and 6 years with a mean GA of 33.54 weeks in the preterm group. In both the abovementioned studies, the preterm children were within the normal spectrum according to the instruments used and showed no difference in gross motor skills when compared to children born fullterm $(37,38)$. As in the present study, a possible explanation for the difference found in relation to the literature may be the higher mean GA and birth weight (BW) when compared to other studies, which evaluated children with a GA of under 33 weeks and weight less than 1,500 g. These results reinforce the importance of expanding research on this population and not restricting studies to children born extremely preterm with extremely low weight.

With respect to caregiver assistance, when preschool age children were assessed, previous studies show that preterm children exhibit greater mobility delays when compared to those born full-term $(25,39)$. The same result was found in the present study. These findings may be related to the fact that the caregivers (parents) of premature children underestimate their abilities in this area (39), offering more help than their fullterm counterparts.
Another factor that may explain these results is that, when compared to full-term children, caregivers of preterm children tend to be more dominant in their interaction with the child for longer time periods $(34,39)$. According to Maggi et al. (23), this behavior may be attributed to the fact that preterm children tend to be more easily distracted and have difficulty completing the tasks requested, requiring greater participation by the caregiver and resulting in less participation by the children themselves. Additionally, caregivers may also help preterm children more because they feel protective towards them $(34,39)$. These children are considered vulnerable since they were exposed to a biological risk factor at birth, which may lead to the underestimation of their abilities $(34,39)$.

Moreira et al. (35) found that a positive family environment promotes development and can reduce or compensate for problems stemming from premature birth, whereas a negative environment may exacerbate the adverse effects related to the biological risk factor $(35,40)$. Thus, the social and environmental context of the family can serve as a protective mechanism against motor impairment, depending on the presence of external resources, such as the physical/material aspects of the environment, as well as the social and human elements and interaction with the caregiver (35). Furthermore, these resources can also have a positive impact on child development $(35,41)$. Indeed, studies have found that better quality resources in the home may lead parents to better care for their children and be more likely to follow the recommendations of educational and healthcare professionals $(35,40,41)$.

The small number of participants precluded subdividing the PTG according to degree of prematurity to determine whether this factor could affect the outcome studied. The proximity of the age range studied to the maximum age of the instrument used may have allowed many of the children to obtain maximum scores in the test. As such, instruments that assess functional performance using more elaborate tasks and a wider age range when evaluating these children are suggested. This would help identify other areas not addressed in the instrument used. Additionally, longitudinal studies with a larger number of participants could contribute to a better understanding of the long-term effects of prematurity.

The results of the present study are encouraging, but it is important to underscore that other issues 
should be monitored in premature children, such as the possibility of behavioral and learning problems. Moreover, the findings highlight the importance of identifying groups that really need long-term follow-up in relation to functionality as opposed to generating the stigma of vulnerability over the lifetime of preterm children.

\section{Conclusion}

The present study contributes to the literature by providing a positive perspective on the development of children born prematurely, demonstrating that children who exhibit this risk factor at birth, but show no primary deficits may overcome functionality issues by the age of 5 to 7 years and no longer display clinically diagnosed impairments associated with preterm birth. However, it also shows that despite the lack of differences in functional skills in relation to children born full-term, caregivers still tend to participate more in their activities at home.

\section{References}

1. Stephens BE, Vohr BR. Neurodevelopmental Outcome of the Premature Infant. Pediatr Clin North Am. 2009;56(3):631-46.

2. Beck S, Wojdyla D, Say L, et al. The worldwide incidence of preterm birth: a systematic review of maternal mortality and morbidity. Bull World Health Organ. 2010;88(1):31-8.

3. Zomignani AP, Zambelli HJL, Antonio MARGM. Desenvolvimento cerebral em recém-nascidos prematuros. Rev Paul Pediatr. 2009;27(2):198-203.

4. Carvalho M, Gomes MASM. Mortality of very low birth weight preterm infants in Brazil: reality and challenges. J Pediatr (Rio J). 2005;81(1 Suppl):S111-8.

5. Friedrich L, Corso AL, Jones MH. Prognóstico pulmonar em prematuros. J Pediatr (Rio J). 2005;81(1 Suppl 1):S79-88.

6. Hack M, Costello DW. Decrease in frequency of cerebral palsy in preterm infants. Lancet. 2007;369(9555):7-8.

7. Allen MC, Cristofalo EA, Kim C. Outcomes of Preterm Infants: Morbidity Replaces Mortality. Clin Perinatol. 2011;38(3):441-54.
8. Colvin M, MCGuire W, Fowlie PW. Neurodevelopmental outcomes after preterm birth. BMJ. 2004;329:1390-3.

9. WORLD HEALTH ORGANIZATION - WHO. International statistical classification of diseases and related health problems. 10th revision. 2010.

10. World Health Organization. Born too soon: the global action report on preterm birth. Geneva: WHO; 2012.

11. Blencowe H, Cousens S, Oestergaard MZ, Chou D, Moller A, Narwal R, et al. National, regional, and worldwide estimates of preterm birth rates in the year 2010 with time trends since 1990 for selected countries: a systematic analysis and implications. Lancet. 2012;379(9832):2162-72;

12. Blencowe $\mathrm{H}$, Lee $\mathrm{AC}$, Cousens $\mathrm{S}$, Bahalim $\mathrm{A}$, Narwal R, Zhong N, et al. Preterm birth associated neurodevelopmental impairment estimates at regional and global level for 2010. Pediatr Res. 2013;74(Suppl 1):17-34.

13. Silveira MF, Santos IS, Matijasevich A, Malta DC, Duarte EC. Nascidos pré-termo no Brasil entre 1994 e 2005 conforme o Sistema de Informações sobre Nascidos Vivos (SINASC). Cad Saude Publica. 2009;25(6):1267-75.

14. Silveira, MF, Santos IS, Barros AJD, Matijasevich A, Barros FC, Victora CG. Aumento da prematuridade no Brasil: revisão de estudos de base populacional. Rev Saude Publica. 2008;42(5):957-64.

15. Barros AJD, Santos IS, Victora CG, Albernaz EP, Domingues MR, Timm LK, et al. Coorte de Nascimentos de Pelotas, 2004: metodologia e descrição. Rev Saude Publica. 2006;40(3):402-13.

16. Barros FC, Victora CG, Barros AJ, Santos IS, Albernaz $\mathrm{E}$, Matijasevich $\mathrm{A}$, et al. The challenge of reducing neonatal mortality in middle-income countries: findings from three Brazilian birth cohorts in 1982, 1993, and 2004. Lancet. 2005;365(9462):847-54.

17. Brasil. Ministério da Saúde. DATASUS. Informações de Saúde- Estatísticas Vitais- Mortalidade e Nascidos Vivos: nascidos vivos desde 1994. [cited 2016 May 29]. Available from: https://tinyurl.com/y9p9e47r.

18. Assunção PL, Novaes HMD, Alencar GP, Melo ASO, Almeida MF. Desafios na definição da idade gestacional em estudos populacionais sobre parto pré-termo: o caso de um estudo em Campina Grande (PB), Brasil. Rev Bras Epidemiol. 2011;14(3):455-66. 
19. Hodek J, Schulenburg JV, Mittendorf T. Measuring economic consequences of preterm birth Methodological recommendations for the evaluation of personal burden on children and their caregivers. Health Econ Rev. 2011;1(6):1-10.

20. Ramos HAC, Cuman RKN. Fatores de risco para prematuridade: pesquisa documental. Esc Anna Nery. 2009;13(2):297-304.

21. Saigal S, Doyle LW. An overview of mortality and sequelae of preterm birth from infancy to adulthood. Lancet. 2008;371(9608):261-9.

22. Zwicker JG, Harris SR. Quality of Life of Formerly Preterm and Very Low Birth Weight Infants From Preschool Age to Adulthood: A Systematic Review. Pediatrics. 2008;121(2):e366-76.

23. Maggi EF, Magalhães LC, Campos AF, Bouzada MCF. Preterm children have unfavorable motor, cognitive, and functional performance when compared to term children of preschool age. J Pediatr (Rio J). 2014;90(4):377-83.

24. Mancini MC, Megale L, Brandão MB, Melo APP, Sampaio RF. Estudo do desenvolvimento da função motora aos 8 e 12 meses de idade em crianças nascidas pré-termo e a termo. Arq Neuro-Psiquiatr. 2002;60(4):974-80.

25. Lemos RA, Frônio JS, Ribeiro LC, Demarchi RS, Silva J, Neves LAT. Desempenho funcional segundo a idade gestacional e o peso ao nascer de crianças em idade pré-escolar nascidas prematuras ou com baixo peso. J Hum Growth Dev. 2012;22(1):1-11.

26. Silva AJ. Morbimortalidade dos neonatos egressos de UTI neonatal em JUIZ DE FORA: fatores associados [master's thesis]. Juiz de Fora, MG: Universidade Federal de Juiz de Fora; 2010.

27. Mancini MC. Inventário de Avaliação Pediátrica de Incapacidade (PEDI) - manual da versão brasileira adaptada. Belo Horizonte: Editora UFMG; 2005.

28. Chagas PSC, Mancini MC. Instrumentos de classificação e de avaliação para uso em crianças com paralisia cerebral. In: Fonseca LF, Lima CLA. Paralisia Cerebral neurologia, ortopedia, reabilitação. 2nd ed. Rio de Janeiro: MedBook; 2008.
29. Brasil. Associação Brasileira de Empresas de Pesquisa (ABEP): Critério de classificação econômica. 2014 [cited 2014 Jun 24]. Available from: https://tinyurl.com/y8fngch4.

30. Cardoso AA, Magalhães LC, Barbosa VM. Desenvolvimento psicomotor em crianças prétermo e a termo na idade escolar. Rev Bras Crescimento Desenvolv Hum. 2011;21(2):210-9.

31. Oliveira GE, Magalhães LC, Salmela LF. Relação entre muito baixo peso ao nascimento, fatores ambientais e o desenvolvimento motor e cognitivo de crianças aos 5 e 6 anos. Revs Bras Fisioter. 2011;15(2):138-45.

32. Marlow N, Wolke D, Bracewell MA, Samara M. Neurologic and Developmental Disability at Six Years of Age after Extremely Preterm Birth. N Engl J Med. 2005;352:9-19.

33. Magalhães L, Catarina $\mathrm{P}$, Barbosa V, Mancini $\mathrm{M}$, Paixão M. Estudo comparativo sobre o desempenho perceptual e motor na idade pré-escolar em crianças nascidas pré-termo e a termo. Arq NeuroPsiquiatr. 2003;61(2A):250-5.

34. Sullivan MC, Msall ME. Functional performance of preterm children at age 4 . J Pediatr Nurs. 2007;22(4):297-309.

35. Moreira RS, Magalhães LC, Alves CRL. Effect of preterm birth on motor development, behavior, and school performance of school-age children: a systematic review. J Pediatr (Rio J). 2014;90(2):119-34.

36. Foulder-Hughes LA, Cooke RW. Motor, cognitive, and behavioural disorders in children born very preterm. Dev Med Child Neurol. 2003;45(2):97-103.

37. Camargos ACR, Fontes PLB, Araújo APS, Silva FC, Pereira LP, Souza SMF. Desenvolvimento motor de crianças pré-termo moderadas aos sete e oito anos de idade. Fisioter Pesqui. 2011;18(2):182-7.

38. Ribeiro ASC, Formiga CKMR, David AC. Healthy preterm infants: global motor coordination and early intervention. Fisioter Mov. 2015;28(1):85-95. 
39. Mancini MC, Megale L, Brandão MB, Melo APP, Sampaio RF. Efeito moderador do risco social na relação entre risco biológico e desempenho funcional infantil. Rev Bras Saude Mater Infant. 2004;4(1):25-34.

40. Nobre FDA, Carvalho AEV, Martinez FE, Linhares MBM. Estudo Longitudinal do Desenvolvimento de Crianças Nascidas Pré-Termo no Primeiro Ano Pósnatal. Psicol Reflex Crit. 2009;22(3):362-9.
41. Martins IMB, Linhares MB, Martinez FE. Indicadores de desenvolvimento na fase pré-escolar de crianças nascidas pré-termo. Psicol Estud. 2005;10(2):235-43.

Received in $05 / 27 / 2016$

Recebido em 27/05/2016

Approved in 04/18/2017

Aprovado em 18/04/2017 